\title{
Correction to: Economic anatomy of Rheidae and its implication for the archaeological record
}

\author{
Miguel A. Giardina ${ }^{1}$
}

Published online: 24 July 2019

(C) Springer-Verlag GmbH Germany, part of Springer Nature 2019

\section{Correction to: Archaeological and Anthropological Sciences https://doi.org/10.1007/s12520-018-0659-x}

The original version of this article, unfortunately, contained errors. The below references were missing from the original publication.

Giardina MA (2006) Anatomía económica de Rheidae. Intersecciones en Antropología 7: 263-276.

Giardina MA (2010) El aprovechamiento de la avifauna entre las sociedades cazadoras-recolectoras del Sur de Mendoza, un enfoque arqueozoológico. Tesis Doctoral Universidad Nacional de La Plata, Facultad de Ciencias Naturales y Museo. MS.

Giardina MA (2010) Human exploitation of Rheidae in North Patagonia, Argentina (South America). Birds in archaeology. Barkhuis, Groningen, 97-102.

Publisher's note Springer Nature remains neutral with regard to jurisdictional claims in published maps and institutional affiliations.

The online version of the original article can be found at https://doi.org/ 10.1007/s12520-018-0659-x

Miguel A. Giardina

mgiardina@mendoza-conicet.gob.ar

1 CONICET-IANIGLA, Museo de Historia Natural de San Rafael,

Parque Mariano Moreno, San Rafael, Mendoza, Argentina 